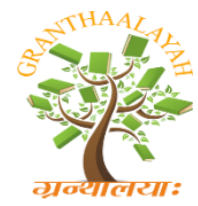

INTERNATIONAL JOURNAL OF RESEARCH GRANTHAALAYAH A knowledge Repository

Management

\title{
BRAND PREFERENCE AND THE PURPOSE OF USING MALTED FOOD DRINKS: A FIELD STUDY IN KANYAKUMARI DISTRICT, SOUTH INDIA
}

\author{
S. Shiny ${ }^{*}$, Dr.C.Eugine Franco ${ }^{2}$ \\ ${ }^{* 1}$ Research Scholar (PT) \& Asst. Professor of Commerce, St. Xavier's College, Palayamkottai, \\ India \\ ${ }^{2}$ Associate Professor of Commerce, St. Xavier's College, Palayamkottai, India \\ DOI: https://doi.org/10.29121/granthaalayah.v5.i4(SE).2017.1951
}

\begin{abstract}
Health is Wealth and is a valuable treasure of one's life; hence it is the duty of every human being to safeguard his or her health very carefully to preserve health with nutritious food. Nutritious food is very much needed in order to maintain our body health. Health drinks are good nutrition drinks for all categories of people to maintain good health and the health food drinks are popularly used as a milk additive for better nutrition and taste. Health food drinks are added to the diet to boost overall health and energy, to provide immune System support and reduce the risk of illness and age related conditions, to improve performance in athletic and mental activities and to support the healing process during illness. In this context, this study is going to analyse Brand Preference and the Purpose of Using Malted Food Drinks: A Field Study in Kanyakumari District, South India.
\end{abstract}

Keywords: Health; Consumer; Human Being; Preference \& Malted Food Drinks.

Cite This Article: S. Shiny, and Dr.C.Eugine Franco. (2017). "BRAND PREFERENCE AND THE PURPOSE OF USING MALTED FOOD DRINKS: A FIELD STUDY IN KANYAKUMARI DISTRICT, SOUTH INDIA.” International Journal of Research Granthaalayah, 5(4)SE, 69-82. https://doi.org/10.29121/granthaalayah.v5.i4(SE).2017.1951.

\section{Introduction}

Consumer is the prime focus around which the entire system of marketing revolves. All marketing starts and ends with the customer, thus the customer is a very important person to a marketer. Understanding consumer preferences is very important whether you are selling a product or offering a service. The basic objective of any business is profit maximization through customer satisfaction. 


\section{Nutrition and Health Drinks}

Nutrition is important for everyone and it the science that deals with food and the way the body using them. When combined with being physically active and maintaining a healthy weight, eating well is an excellent way to help body stay strong and healthy. The essential nutrients for life include carbohydrates, proteins and Fats as well as fiber, vitamins, minerals and water- the solvent for all soluble ingredients in the blood and cells. Good nutrition means getting the right amount of nutrients from healthy foods in the right combinations. There are innumerable brands of malted food drinks that try to influence the buyers.

Health drinks are the essential materials through which the body is conditioned for its wellbeing. The good food is indispensable for health at all stages of the life and for satisfactory growth during infancy, childhood, adolescence and adulthood. It is powdered beverage food which consists of protein, carbohydrate, fats, vitamins, minerals etc., essential for good health. Indian Health-drinks Industry $v$ Divided into two categories - White powders (Horlicks, Complan etc) and Brown powders (Bournvita, Boost etc) $v$ Health drink powders consumed as milk substitute \& nutrient boosters $v$ India ${ }^{e e}$ s Health-drinks market pegged at around 4000 crores (90000 tonnes) and expected to reach approximately 8000 crores by $2016 \mathrm{U}$ India is world ${ }^{\text {ee }} \mathrm{s}$ largest malt-based drinks market with a share of almost $22 \%$ in the world ${ }^{\text {ee }} \mathrm{s}$ total retail volume(Malt is germinated cereal grains that have been dried in a process known as malting) White Powders $\sim 65 \%$ Brown Powders $~ 35 \%$

\section{Statement of the Problem}

In this modern world, all health drinks are gaining popularity. Every day one's wakes up to an advertisement announcing the arrival of new health drinks in the market. Consumers have created unique characteristics. Each one differs from other one. Because of heavy competition, it is essential to every marketer must understand the consumer behavior.

Paying attention to customers is key to understanding their likes and dislikes. The negative experience of a single customer can send away tons of potential customers. It is, therefore, important that, an organization invests as much as possible in understanding customer preferences. The common man finds it too hard to buy the high price health drinks with the changing trends.

\section{Objectives of the Study}

1) To study the socio-economic profile of the respondents.

2) To study about the influencing factors for the usage of health drinks.

3) To evaluate the customer preference towards Health drinks.

4) To analyse the level of satisfaction of the respondents.

5) To offer suitable suggestions for improving the health drinks. 


\section{Scope of the Study}

The present study is to analysis the consumer preference towards health drinks in Kanyakumari District with the help of data collected from the consumers of health drinks. The study analysis from the point of view of consumer in various aspects like product, price, quality and quantity which make a consumer to buy the products.

\section{Methodology of the Study}

The validity of any research is based on the data collected for the study. The present study is based on both primary as well as secondary data. The primary data were collected from selected respondents of Kanyakumari District by using Interview schedule method. Secondary data were collected from books, journals, magazines and websites.

\section{Period of the Study}

The study was conducted for the period of five months from June 2016 to December 2016.

\section{Sample Size}

The sample size selected for this study is 120 respondents. The respondents are selected by simple random sampling method.

\section{Statistical Tools of the Study}

The following statistical techniques have been used for the Study.

1) Simple percentage analysis

2) Chi-square test.

3) Garrett Ranking

\section{Review of Literature}

For the purpose of the study, relevant studies related to consumer behaviour have been reviewed.

Dr.Muthamizh Vendan Murugavel (2010), conducted a study to measure consumer's satisfaction towards malted food products and to study problems faced by the consumer. It was conducted by him that advertising was the major source of information, usage of twice a day was visible in majority of the cases. Refill packing was preferred by the major junk. Quality and performance oriented aspects were given more weightage.

Kumar et.al., (1987), investigated the factors influencing the buying decision for various food products. It was concluded that there was no significant association of country of origin and brand against age, gender and income. Buying decisions were independent of age, education and income. The brand image was the bigger influencing factor than the origin of product.

Kriti Bardhan Gupta (2009), conducted a study to predict the behaviour of consumers for food products in India. It was found that cleanliness, patricides free, freshness, good health and hygiene of place of sale were the prime attributes considered for buying products. 
Dinesh Kumar (2007), in the study conducted to assess the influence of celebrity endorsement on consumers buying behaviour and marketing, found that using of celebrity could change the attitude in favour of the advertisement and celebrity advertisement was more attractive than noncelebrity advertisement in pulling the attention to the advertisement.

Nagaraja.B (2004), was of the opinion that buying behaviour was impacted by own experience, neighbors and family members. The buying decision was greatly influenced by the involvement of family members. Quality and availability were the most prominent factors inducing buying behaviours.

Sritharan et.al., (2008), in the study conducted to analyse the role of involvement in determining brand loyalty, found involvement played a predominant role in influencing brand loyalty. Consumer involvement had been measured using consumer involvement profile.

Jabir Ali et.al., (2010), in the study conducted to examine buying behaviour of consumers for food and grocery products, found that consumers preference for the above products was based on the factors given in the descending order of quantum of influence namely price, quality, variety, packing and non-seasonal availabilities.

Arpita Khare and Sapna Rakesh (2011), conducted a study to analysis the factors involved in identifying buying decisions in the high and low involvement category products among Indian youth. As per the finding, brand function assumed a greater role in influencing consumer behaviour for high involvement products whereas advertising played an important role in the purchase decision of low involvement products.

Ramasamy et.al., (2005), in their study, derived that the buying behaviour was greatly impacted by awareness and attitude formed towards the product. Commercial advertisement in TV was understood as the prime source of information followed by retail outlet display. Price followed by the image of the company was considered as the major indicator of quality.

Nandagopal and Chinnaiyan (2003), in the study conducted to ascertain brand preference for soft drinks in rural area of Taminadu, found that rural consumers have a high brand awareness for a good number of soft drink's brands. Soft drinks were purchased buy direct mentioning of brand name. Quality followed by retail price was the major influencing factors of brand preferences. Availability was also another important factor inducing the preference for the particular brand.

Mukesh Dhunna (1984), in a case study conducted to analysis consumer behaviour with regards to soft drinks by thrusting special emphasize on the purchasing pattern and attitude of consumers, constructed that demographic variables such as age, profession, sex and income had the potential to impact differences in attitudes.

Sinha (2003), in this study to evaluate shopping orientation in the evolving Indian Market, came out with the findings that Indian shoppers are included towards emotional and entertainment value of shopping rather than functional value. The type of store, frequency of buying and socioeconomic classification were the important factors determining the orientation. 
Krishna and Aradhana (1991), conducted a study to ascertain the effect of dealing patterns of consumer perceptions of deal frequency and willingness to pay. It was found that he price, consumer is willing to pay for a brand is positively and significantly correlated with perceived deal frequency than with actual deal frequency.

In a study conducted by market research agency Indicate research among 1200 adults in Delhi and Mumbai to analyse usage and attitude towards packaged fruit juices, found that packaged fruit juices it recognized as social drinks and consumed by family members and friends when they are together. Taste, health, parity, nutrition and reasonable price were considered as major determinants in choosing the brand of fruit juices.

\section{Profile of the Popular Brands of Health Drinks}

\section{HORLICKS}

Horlicks is the leading health food drink in India and as the "Most Trusted Drink Brand" in India. Horlicks enjoys more than half of the health food drink market. The modern and contemporary horlicks offers pleasurable nourishment with a delicious range of flavours including vanilla, Toffee, Elachi Chocolate etc. Horlicks is a nourishing malted drinks which some goodness of malted barley, wheat and dairy ingredients. It is a good source of energy and nutrient. Horlicks is sold in a number of countries across the world. In different countries, the product has different formulation in order to carter to varying consumer segments and serve different consumer needs. It helps to meet the requirements of essential nutrients in children, such as iron and vitamins.

Types of Horlicks:

1) Junior Horlicks

2) Mother Horlicks

3) Women's Horlicks

4) Horlicks Lite

5) Horlicks Gold

6) Horlicks Promind

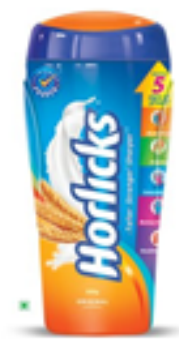

\section{Nutrition Contents and Benefits:}

\begin{tabular}{|l|l|}
\hline Nutrients & Benefits \\
\hline Calcium, Vitamin D, Phosphorus, Magnesium. & Healthy Bones \\
\hline $\begin{array}{l}\text { Iodine, Vitamin B6, Vitamin B12, } \\
\text { Folic Acid, Carbohydrate, Sugar (sucrose). }\end{array}$ & Brain development and its function \\
\hline Iron,Vitamin C, Vitamin A & Healthy blood \\
\hline $\begin{array}{l}\text { Fat,VitaminB1,VitaminB2,Niacin, } \\
\text { Biotin, Pantothenic Acid, Energy }\end{array}$ & Energy and it metabolism \\
\hline Vitamin E, Selenium, Copper, Zinc. & Normal Function of immune system \\
\hline Sodium, chloride & Fluid and electrolyte balance \\
\hline
\end{tabular}




\section{BOOST}

Boost is India's leading malt-based Health Food Drink (HFD) to have used celebrity endorsement to convey its energy proposition. Boost was the first brand to introduce yellow granules in its formulation. Boost is India's only health food drink scientifically proven to increase stamina by 3 times+. Boost has won the prestigious "World Star Award" for its packaging. The tagline "Boost is the secret of our energy" has remained a block buster all through 518 years. Boost is a super brand with lots of lessons for a marketer to learn. The brand continues to invest in it and has remained the favorite of marketers

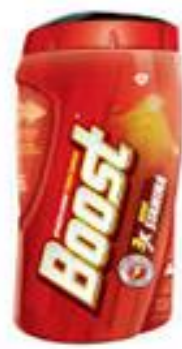
and kids.

Nutrition Contents and Benefits:

\begin{tabular}{|l|l|}
\hline Nutrients & Benefits \\
\hline Iron, Vitamin C & $\begin{array}{l}\text { Important for oxygen transport in the body } \\
\text { essential for Stamina. }\end{array}$ \\
\hline $\begin{array}{l}\text { VitaminB1, Niacin, Biotin, Panthothenic } \\
\text { Acid, Iodine, Magnesium. }\end{array}$ & $\begin{array}{l}\text { Energy release from food for efficient working } \\
\text { of body cells. }\end{array}$ \\
\hline $\begin{array}{l}\text { Vitamin B 12, Folic acid, } \\
\text { Vitamin B2, Vitamin B6. }\end{array}$ & $\begin{array}{l}\text { Help in optimal utilization of oxygen by the } \\
\text { body important for stamina. }\end{array}$ \\
\hline Vitamin D, Calcium, Protein & $\begin{array}{l}\text { Help in maintenance of optimal bone and } \\
\text { muscle health for strength. }\end{array}$ \\
\hline Vitamin A, Copper, Zinc & $\begin{array}{l}\text { Helps to protect from excessive cell damage due } \\
\text { to oxidative stress. }\end{array}$ \\
\hline
\end{tabular}

\section{BOURNVITA}

Bournvita is a tasty and high nutritional supplement drink. It is specially enriched with vitamin D to help better grow for your children's. Cadbury India ltd. Offer bournvita health drink provides the nutrition to aid growth and all round development especially for the Kids. Cadbury Bournvita is one of India's most trusted brand and comes in both a chocolate and caramel flavor. It can increase the physical endurance of a child and enhance the immune system of the body. It is one of the oldest brand in the malted beverages segment. Bournvita has strong competitors like complain and horlicks but still holds a strong position in market.

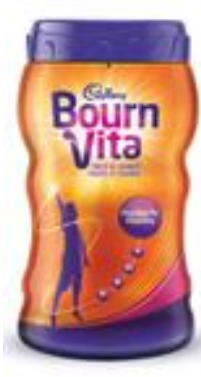
Types of Bournvita:

1) Bournvita Star Magic

2) Bournvita Lil Champs

\section{Nutrition contents and Benefits:}

\begin{tabular}{|l|l|}
\hline Nutrients & Benefits \\
\hline $\begin{array}{l}\text { Energy, Protein, Carbohydrate, sugars, } \\
\text { Total Fat. }\end{array}$ & Source of energy to keep the body active \\
\hline
\end{tabular}




\begin{tabular}{|l|l|}
\hline $\begin{array}{l}\text { Vitamin B1 (thiamin),Vitamin B2 } \\
\text { (Riboflavin), Vitamin B3 (Niacin), } \\
\text { Vitamin B5 (Panthothenic Acid), Biotin }\end{array}$ & $\begin{array}{l}\text { Aids metabolism and helps release energy } \\
\text { from food }\end{array}$ \\
\hline Vitamin B9 (Folic acid), Vitamin B12 & Helps in maintaining healthy blood \\
\hline Vitamin A & Necessary for normal vision \\
\hline Vitamin C, Manganese & Helps to protect the body's cells from damage. \\
\hline Copper, Selenium, Zinc & For healthy functioning of the immune system \\
\hline Vitamin D, Calcium, Phosphorous & Aids development of strong bones and teeth. \\
\hline Pottassium & Controls balance of fluids in the body. \\
\hline Iodine & Necessary for mental development. \\
\hline Iron & $\begin{array}{l}\text { Necessary for formation of Hemoglobin and in } \\
\text { the transport. }\end{array}$ \\
\hline
\end{tabular}

\section{COMPLAN}

Complan is an ideal food for growing children need balanced and adequate nutrition to help them achieve their maximum growth potentiality. In India, the complain brand is owned by the H.J. Heinz company. It is also an ideal nutrition supplement for children height and physical activity, like sports, and games. It provide different flavors such as chocolate, Keser Badam etc,. Complan is a key player in malted food drink category. To extend the goodness of complain and make it available to children any time, the brand was also conceived in a biscuit form.

Types of Complan

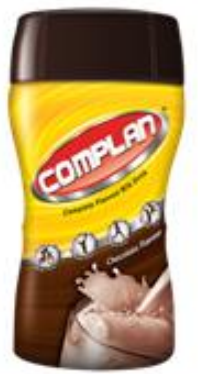

1) Complan Nutri-Gro

2) Complan Memory

3) Complan Kesar Badam

4) Complan Pista Badam

Nutrition Contents and Benefits:

\begin{tabular}{|l|l|}
\hline Nutrients & Benefits \\
\hline Milk Protein & $\begin{array}{l}\text { Essential for rapid growth development and maintenance } \\
\text { of body. }\end{array}$ \\
\hline Fat & Concentrated source of energy and mental alertness. \\
\hline Carbohydrate, Sugr,(sucrose) & Source of energy. \\
\hline $\begin{array}{l}\text { Calcium, Phosphorous, } \\
\text { VitaminD, Sodium, Potassium, } \\
\text { chloride }\end{array}$ & $\begin{array}{l}\text { Strong and healthy bones and healthy Muscles } \\
\text { Maintenance of water balanced in the body. }\end{array}$ \\
\hline $\begin{array}{l}\text { Iodine, Iron, Vitamin B12 } \\
\text { Folic Acid }\end{array}$ & Keep your mentally sharp, alert and Physically active. \\
\hline $\begin{array}{l}\text { Vitamin A, Vitamin E, } \\
\text { Vitamin C, Zinc }\end{array}$ & Develop body Resistance to fight with infection. \\
\hline $\begin{array}{l}\text { Vitamin B1, Vitamin B2 } \\
\text { Vitamin B6, Calcium }\end{array}$ & $\begin{array}{l}\text { Efficient conversion of food to energy, keeping nervous } \\
\text { system healthy. }\end{array}$ \\
\hline
\end{tabular}


Panthothenate.

\section{PEDIASURE}

Pediasure is a source of complete balanced nutrition especially designed for the oral feeding of children 2 to 13 years age. It is a liquid nutrition supplement promoted to help children who need to gain weight. Whether your child has a medical condition that prevents him from taking in enough calories through a standard diet or is just a picky eater, your pediatrician may recommend pediasure to boost his calorie intake. Pediasure is clinically proven to help kids grow. Each kid-approved flavour comes in a reclosable bottle-perfect for kids on the go and on the grow. The flavours such as vanilla and chocolate are available in this health drink. Pediasure was manufactured by Abbott

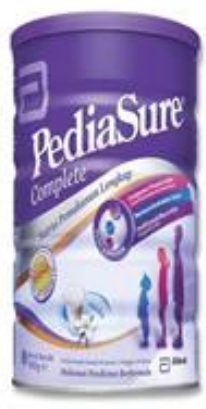
Healthcare Pvt.Ltd.

Types of Pediasure:

1) Pediasure Complete

2) Pediasure Plus

\section{Nutrition Contents and Benefits}

\begin{tabular}{|l|l|}
\hline Nutritional Facts & Benefits \\
\hline Energy, Protein, Fat, Saturated Fatty Acids, & \\
Manounsturated Fatty Acids, Polyunsaturated fatty & It supports Brain development. \\
Acids, Linoleic Acid, Linolenic Acid, Trans & \\
$\begin{array}{l}\text { FattyAcids, holestrol,Carbohydrate,Sugar,Fructo- } \\
\text { oligosaccharides, Taurine, Carnitine Inositel. }\end{array}$ & \\
\hline Vitamins:- & \\
Vitamin A,VitaminD 2 ,VitaminE, Vitamin K, K, & Helps to increase height and weight. \\
Vitamin C, Folic Acid, Vitamin $\mathrm{B}_{1}$, Vitamin $\mathrm{B}_{2}$, & \\
Vitamin $\mathrm{B}_{6}$, Vitamin $\mathrm{B}_{12}$, Niacin, Pantothenic Acid, & \\
Biotin, Choline. & Support for immunity development. \\
\hline Minerals:- & \\
\hline Sodium, Potassium, Chloride, Calcium, & \\
Phosphorus, Magnesium, Iron, Zinc, & \\
Manganese, Copper, Iodine, Selenium & \\
Chromium, Molybdenum. & \\
\hline
\end{tabular}




\section{Analysis and results}

Table 1: Gender Wise Classification

\begin{tabular}{|l|l|l|l|}
\hline Gender & No. of Respondents & $\%$ & \\
\hline Male & 44 & 37 \\
Female & 76 & 63 & \\
\hline Total & $\mathbf{1 2 0}$ & $\mathbf{1 0 0}$ & \\
& & & \\
\hline
\end{tabular}

Source: Primary Data

The table shows that, out of 120 respondents, 37 percentages of the respondents were male and 63 percentage of the respondents were female. It is clear that, mostly females are using health drinks because most of the female are health less.

Table 2: Age-Wise Classification

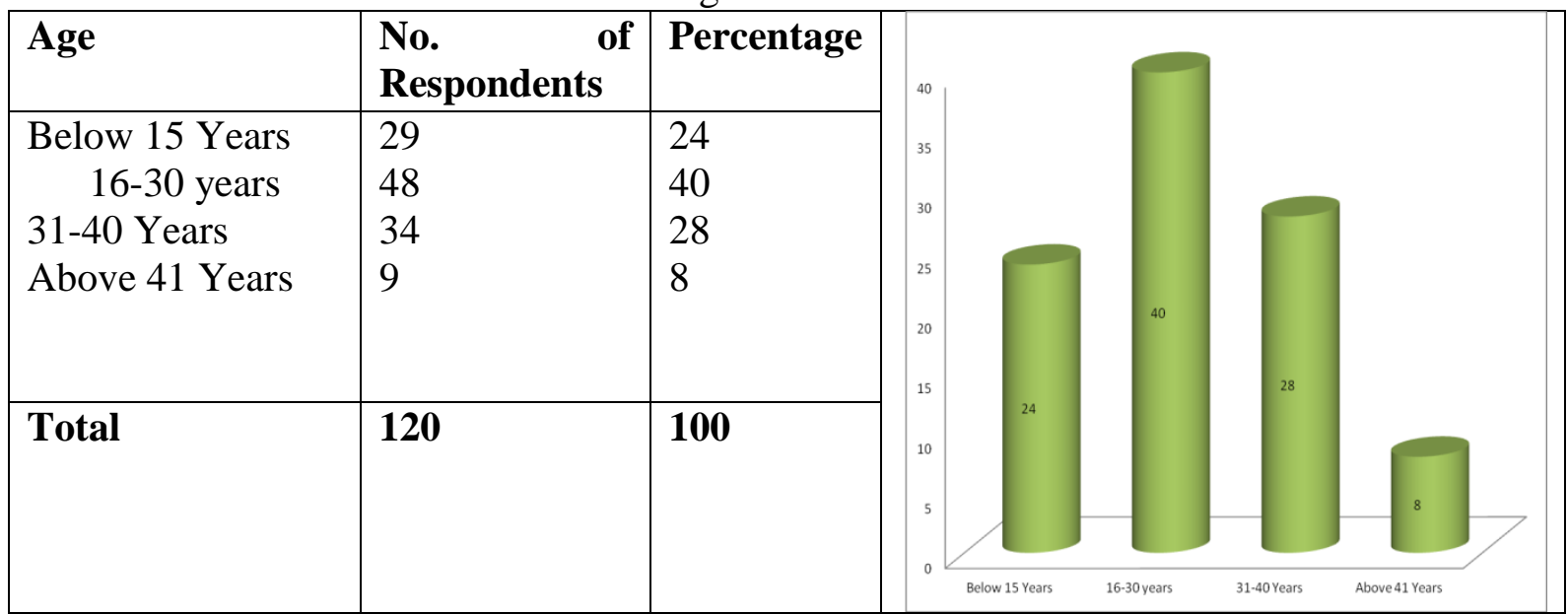

Source: Primary Data.

The table shows that, 24 percentage of the respondents belongs to the age group of below 15 years, 40percentage of the respondents belongs to the age group of 16-30 years, 28 percentage of the respondents belongs to the age group of 31-40 years and 8 percentage of the respondents belongs to the age group of above 41 years. 
Table 3: Educational Qualification

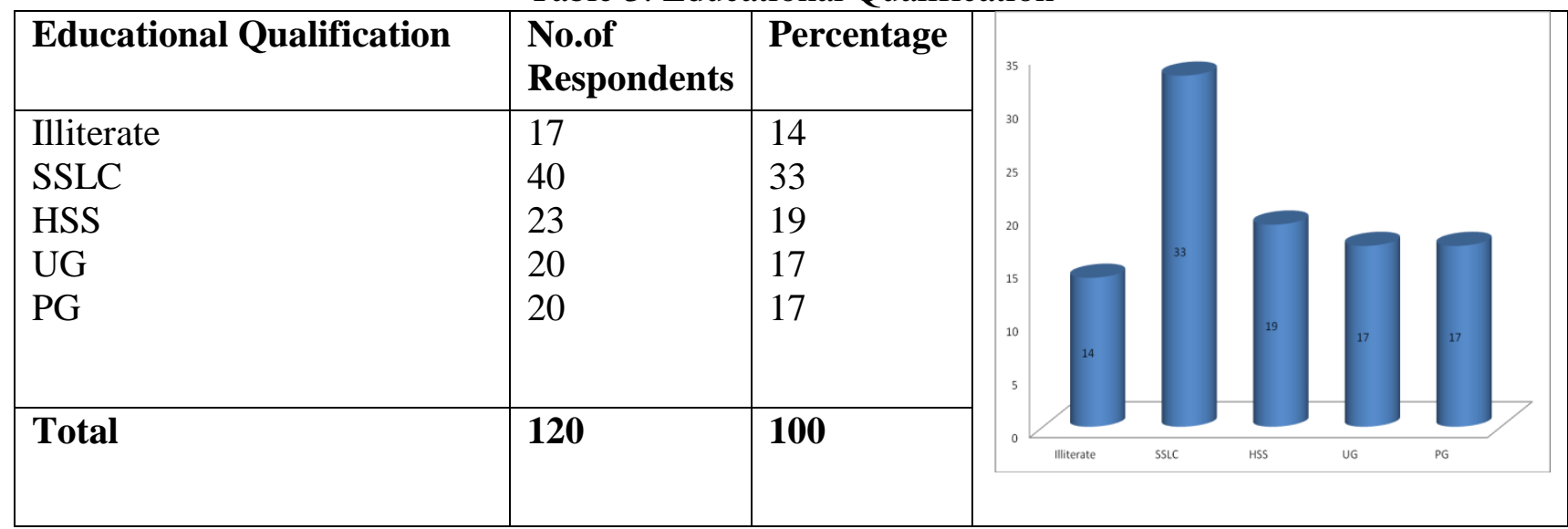

Source: Primary Data.

The table shows that, 14 percentage of the respondents were illiterate, 33 percentage of the respondents were completed SSLC, 19 percentage of the respondents were completed HSS, 17 percentage of the respondents were completed U.G and 17 percentage of the respondents were completed P.G.

Table 4: Occupation of the Respondents

\begin{tabular}{|c|c|c|c|}
\hline Occupation & $\begin{array}{l}\text { No.of } \\
\text { Respondents }\end{array}$ & Percentage & ${ }_{35}$ \\
\hline $\begin{array}{l}\text { Fishing } \\
\text { Govt. Employee } \\
\text { Private Employee } \\
\text { Business } \\
\text { Student } \\
\text { House Wife }\end{array}$ & $\begin{array}{l}14 \\
3 \\
17 \\
13 \\
41 \\
32\end{array}$ & $\begin{array}{l}12 \\
2 \\
14 \\
11 \\
34 \\
27\end{array}$ & ${ }_{15}^{20}$ \\
\hline Total & 120 & 100 & 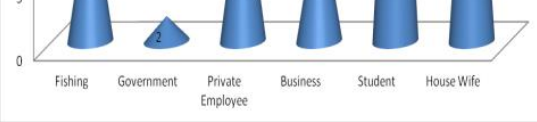 \\
\hline
\end{tabular}

Source: Primary Data.

The table shows that, 12 percentage of the respondents were fisherman, 2 percentage of the respondents were Government employee, 14 percentage of the respondents were private employee, 11 percentage of the respondents were businessman, 34 percentage of the respondents were student and 27 percentage of the respondents were House Wife. 
Table 5: Monthly Income of the Respondents

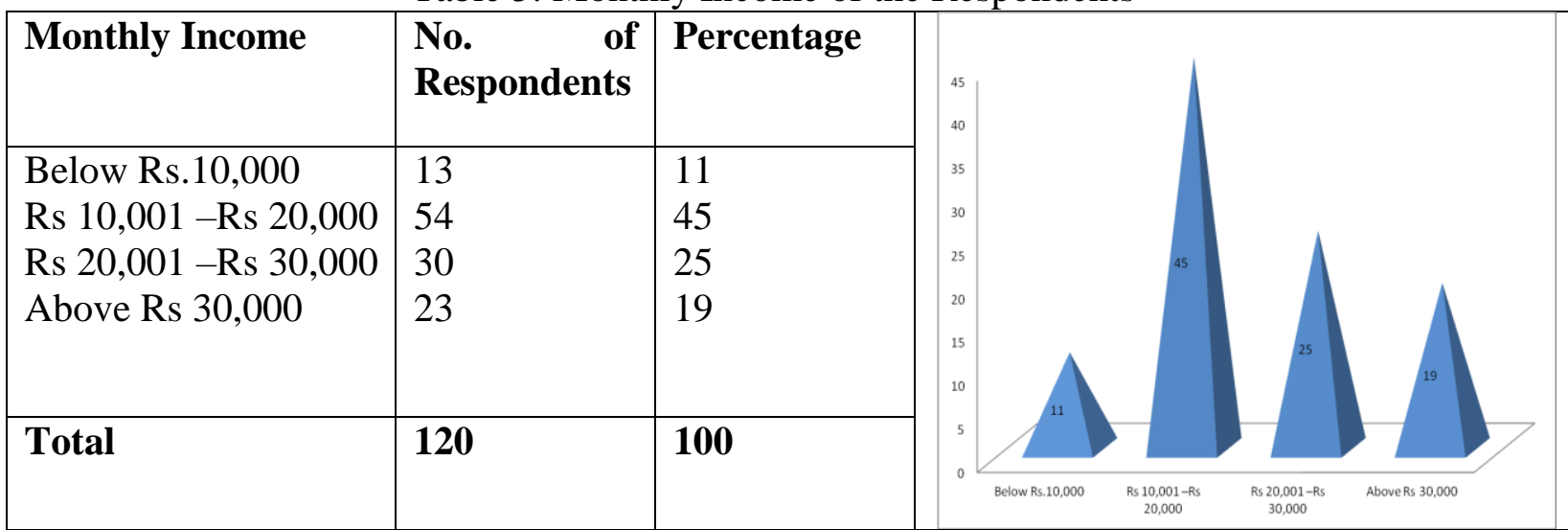

Source: Primary Data

The table shows that, 11 percentage of the respondents belongs to the income level of below Rs $10,000,45$ percentage of the respondents belongs to the income level of Rs 10,001 -Rs 20,000, 25 percentage of the respondents belongs to the income level of Rs 20,001-Rs 30,000 and 19 percentage of the respondents belongs to the income level of above Rs 30,000 .

Table 6: Brand Preference of Health Drinks

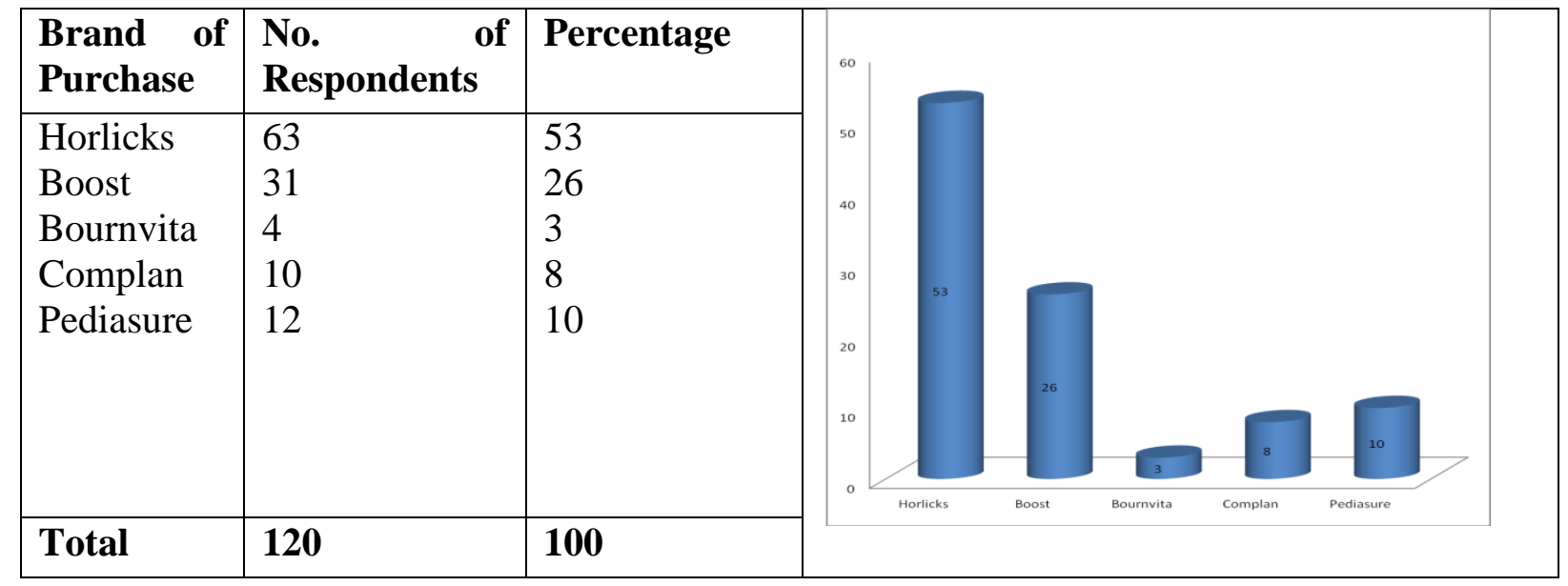

Source: Primary Data.

The table shows that, 53 percentage of the respondents were using Horlicks, 26 percentage of the respondents were using Boost, 3 percentage of the respondents were using Bournvita, 8 percentage of the respondents were using Complain and 10 percentage of the respondents were using Pediasure. 


\section{Garrett Ranking Method:}

Garrett Ranking is used to analysis the purpose of usage of Health Drinks. The present position for the rank is obtained by using the following formula.

$100(\mathrm{Rij}-0.5)$
Present position $=$------------
$\mathrm{Nij}$

Rij - Rank given by the purpose of usage Nij - Individual Ranked.

Table 7: Purpose of Usage

\begin{tabular}{|l|l|l|l|l|l|l|}
\hline Purpose of Usage & I & II & III & IV & V & Total \\
\hline Increase Energy & 48 & 24 & 5 & 40 & 3 & 120 \\
Increase Height & 18 & 25 & 16 & 4 & 57 & 120 \\
Increase Weight & 35 & 6 & 21 & 25 & 33 & 120 \\
Increase Immunity & 11 & 35 & 49 & 21 & 4 & 120 \\
Improve concentration and memory & 8 & 30 & 29 & 30 & 23 & 120 \\
\hline Total & $\mathbf{1 2 0}$ & $\mathbf{1 2 0}$ & $\mathbf{1 2 0}$ & $\mathbf{1 2 0}$ & $\mathbf{1 2 0}$ & - \\
\hline
\end{tabular}

Garrett Ranking Results

\begin{tabular}{|c|c|c|c|}
\hline Purpose of Usage & $\begin{array}{l}\text { Mean } \\
\text { Square }\end{array}$ & Rank & 60 \\
\hline Increase Energy & 58.04 & I & \\
\hline Increase Height & 43.63 & $\mathrm{~V}$ & \\
\hline Increase Weight & 48.83 & III & ${ }_{40}$ \\
\hline Improve immunity & 52.63 & II & 3 \\
\hline $\begin{array}{l}\text { Improve Concentration } \\
\text { and memory }\end{array}$ & 46.88 & IV & \\
\hline
\end{tabular}

While applying Garrett Ranking analysis the researchers conclude that the purpose of usage of particular brand of health drinks. Increase energy as it scores 58.04 points and got first rank, next category is Increase Height as it Scores 43.63 points and got fifth rank, next category is Increase Weight as it Scores 48.83 points and got third rank, next category is Improve Immunity as it Scores 52.63 points and got Second rank and next category is Improve Concentration and Memory as it Scores 46.88 points and got fourth rank.

\section{Findings}

1) The study discloses that, the majority of the respondents belongs to the income group of Rs.10, 001 - Rs.20,000

2) The study reveals that, the majority of the respondents preferred Horlicks

3) The study shows that, the respondents gives first rank to the purpose of increase energy. 
4) The study discloses that, the majority of the respondents were influenced by their children.

5) The study reveals that, the majority of the respondents were influenced by advertisement.

\section{Suggestions}

1) The marketers are advised to receive the feedback from the customers.

2) Marketer should take necessary steps to know about the current position of their products and competitor's product in the market.

3) It is suggested to employ more sales promotional activities to increase the sale of health drinks in the market.

4) Efficient advertisement should be introduced to improve the sales.

5) Attractive reusable package can be offered to attract the customers easily.

\section{Conclusion}

Malted food drinks made humble beginning into the families of India and has established itself in the consumer market to a larger extent. From this study one may come to a conclusion that the wide variety of products is available in the market to the buyers of all segments. However, the Indian buyers mostly concentrate in the consumption of Horlicks which has reached every corner of the country. In the study area as per the results it is understood that Horlicks followed by Boost remains well in the minds of the buyers. People are health conscious and are interested to capitalize the features and availability of the product in the market than their other initiatives to reach-out the buyers.

\section{References}

[1] Armstrong, G. \& Kotler, P. 2005. Marketing: An Introduction. New Jersey: Pearson Education, Inc.

[2] Berkowitz E.N., Kerin R.A., Hartley S.W., Rudelius W. (1992): Marketing. 3th edition, Irwin, Boston; ISBN 0-256-09182-X.

[3] Connors M., C.A Bisogni, J. Sobal and C.M. Devine (2001), Managing Value in personal food items. Appetite; 36:189-200.

[4] DU PLESSIS, PJ \& ROUSSEAU, GG. 1999. Buyer behaviour. A multi cultural approach. Halfway House. International Thomson. Sigma.. :176.

[5] Golden, S. A. R. (2016). Customers' Attitude Towards Online Shopping - An Analysis. International Journal of Business and Administration Research Review, 1(1), 453-455.

[6] Golden, S. A. R. (2017). Recent Research In Social Science \& Humanities. Harlow:Pearson Education Limited.

[7] Kotler, P. 2000. Marketing management 10th ed. New Jersey: Prentice-Hall. :163

[8] Kotler, P.; Wong, V.; Saunders, J. \& Armstrong, G. 2005. Principles of Marketing. Harlow: Pearson Education Limited p. 148.

[9] Kotler, P.; Wong, V.; Saunders, J. \& Armstrong, G. 2005. Principles of Marketing.

[10] Regi, S. B., \& Golden, S. A. R. (2014). A DESCRIPTIVE STUDY ON THE ROLE OF CONSUMER PSYCHOLOGY AND BEHAVIOUR IN PRODUCT PURCHASING”. Indian Streams Research Journal, 3(12), 1-6.

[11] Regi, S. B., Golden, S. A. R., \& Franco, C. E. (2014). A DESCRIPTIVE STUDY ON THE PROSPECTS OF E-COMMERCE IN INDIA. Golden Research Thoughts, 3 (9), 1, 7. 
[12] Regi, S. B., Golden, S. A. R., \& Franco, C. E. (2014). ROLE OF COMMERCIAL BANK IN THE GROWTH OF MICRO AND SMALL ENTERPRISES. Golden Research Thoughts, 3(7), $1-5$.

[13] Solomon, M.R. 2002. Consumer behaviour: Buying, having and being 5th ed. New Jersey: Prentice-Hall. 288.

[14] Venkatesh, Alladi, (1994), India's Changing Consumer Economy: A Cultural Perspective. "Advances in Consumer research, 21: 323-328. 